\title{
Articles
}

\section{Copper(II), Nickel(II) and Palladium(II) Complexes of 2-Oximino-3-thiosemicarbazone-2,3-butanedione}

\author{
Abdulla H. Al-Kubaisi \\ Chemistry Department, Facult? of Science, University of Qatar, Doha-P.O. Bor 27/3. Qatar \\ Received March 18,2003
}

\begin{abstract}
A new tridentate ligand incorporating a monoxime and thiosemi-carbozone moieties has been synthesized. Its copper(II), nickel(II) and palladium(II) complexes have been prepared and characteirzed by physical and spectral methods. Flemental analyses and spectroscopic data of the metal complexes are consistent with the formation of a mononuclear copper(II) complex and binuclear complex with both nickel(II) and palladium(II). In the copper(II) complex the fourth coordination site is occupied by nitrate ion. In the binculear complexes the fourth coordination site is occupied by the deprotonated oxime oxygen of the ligand coordinated to the other metal.
\end{abstract}

Key Words : 2-Oximino-3-thiosemicarbazone-2,3-butanedione, Copper(II), Nickel(II), Palladium(II), Complexes

\section{Introduction}

During the last decade, great attention has been given to the area of multinuclear complexes with extended bridges, 1.2 mainly because of the need to gain insight into the electron transfer pathways in biological systems. ${ }^{3}$ Several metal complexes have been synthesized in order to obtain detailed information about the exchange mechanism in these systems since biomolecules with multinuclear metal centres are known to be involved in important biological processes such as catalysis. ${ }^{1.5}$ The homomultinuclear copper complexes of macrocyclic or macroacyclic ligands have been reported to undergo redox reactions similar to the active sites in several metalloproteins and has also proved to be efficient catalysts under mild conditions. ${ }^{6-8}$ Complexes with mixed oxime and Schiff base ligands coordinated to $C$ (III) have been reported to show superior electrochemical properties and biological behavior, as vitamin $\mathrm{B}_{12}$ mimics, than do the complexes with either oxime or Schiff base ligands alone." 10

The chemistry of transition metal complexes of thiosemicarbazone has been investigated extensively. These studies were largely driven by their biological properties. ${ }^{1.12}$ Thiosemicarbazone usually coordinates to a metal ion either by the neutral thione form or by the anionic thiolate form."

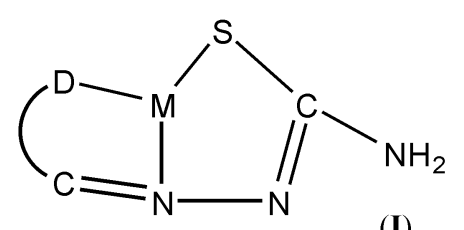

(I)

"Fax: (0974) 483506I, e-mail: a kubaisi (aqu.edu.qa
However, incorporation of a third donor site (D) into these thiosemicarbazone ligands linked to the carbonylic carbon via one or two intervening atoms usually results in D,N,S tricoordination ${ }^{11}$ as shown in (I).

Though, the thiosemicarbazone moiety of the free tridentate ligand (I) exists in the thione form, ${ }^{13}$ it is known to bind as a dianionic tridentate D,N,S donors. ${ }^{\text {l. }}$

The present paper describes the syntheses and characterization of the new ligand 2-oximino-3-thiosemicarbazone, 2.3-butanedione ( $\mathrm{H}_{2}$ otscb) and its new complexes with $\mathrm{Cu}(\mathrm{II}), \mathrm{Ni}(\mathrm{II})$ and $\mathrm{Pd}(\mathrm{II})$. The properties of the complexes were investigated by magnetic, cyclic voltammetry and spectroscopic methods. The study of oxime metal chelates are of special interest owing to their biological activities and semi conducting properties. ${ }^{15}$

\section{Experimental Section}

\section{Preparation of ligand and complexes:}

Schiff base 2-oximino-3-thiosemicarbazone-2,3-butanedione, (H $\mathbf{H}_{2}$ otscb), (II): 2,3-butanedione monoxime (8.1 g, $80 \mathrm{mmol})$ and thiosemicarbazide $(7.3 \mathrm{~g} .80 \mathrm{mmol})$ were mixed in $85 \%$ ए to $\mathrm{H} / \mathrm{H}_{2} \mathrm{O}(250 \mathrm{ml}$ ). The mixture was boiled under reflux with stirring for $4 \mathrm{~h}$. The solution was reduced to half of its original volume on a water bath and the resulting white solid was collected by suction filteration and washed with cold $\mathrm{EtOH}$. The crude product was recrystallized from $\mathrm{TtOH}$ as a white crystalline plates, yield $(90 \%)$, m.p. $200^{\circ} \mathrm{C}$.

Copper(II) complex [Cu(Hotscb)( $\left.\mathrm{NO}_{3}\right)\left(\mathrm{H}_{2} \mathrm{O}\right) \mid$, (III): A solution of $\mathrm{Cu}\left(\mathrm{NO}_{3}\right)_{2} \cdot 3 \mathrm{H}_{2} \mathrm{O}(1.2 \mathrm{~g}, 5 \mathrm{mmol})$ in $\mathrm{EtOH}(20$ $\mathrm{mL}$ ) was added to a warm solution of ( $\left.\mathrm{H}_{2} \mathrm{otscb}\right)(0.88 \mathrm{~g}, 5$ mmol) in $\Gamma \mathrm{tOH}(20 \mathrm{~mL})$. The mixture was boiled under 
reflux for $1 \mathrm{~h}$. The resulting green preciptate was filtered off, washed several times with $\mathrm{F} . \mathrm{OH}$ and $\mathrm{Ft}_{2} \mathrm{O}$ and dried in vacuo, yield $(65 \%)$; m.p. $220^{\circ} \mathrm{C}$.

Nickel(II) complex |Ni(otscb)| $\left.\right|_{2}$, (IV): To a solution of $\left(\mathrm{H}_{2}\right.$ otscb) $(0.88$ g. $5 \mathrm{mmol})$ in FtoH $(40 \mathrm{~mL})$ was added a solution of $\mathrm{Ni}$ (acetate) $)_{2} 4 \mathrm{H}_{2} \mathrm{O}(1.22 \mathrm{~g}, 5 \mathrm{mmol})$ in $\mathrm{CtOH}(20$ $\mathrm{ml}$.). The mixture was boiled under reflux with stirring. After a few minutes brown microcrystals deposited, the reflux was continued for $\mathrm{Ca} 2 \mathrm{~h}$. The brown precipitate was collected by filteration, washed thoroughly with $\mathrm{EtOH}$ and F $t_{2} \mathrm{O}$ and dried in vacuo, yield $(85 \%) ; \mathrm{mp}>300^{\circ} \mathrm{C}$.

Palladium(II) complex |Pd (otscb) $\left.\right|_{2},(\mathrm{~V})$ : This complex was prepared using $\mathrm{Pd}$ (acetate) 2 following the procedure used above, stirring was continued for $5 \mathrm{~h}$ at room temperature and the resulting red microcrystals were collected by suction filteration, Yield (85\%) m.p. $270^{\circ} \mathrm{C}$.

The ligand and the three complexes were characterized by their elemental and thermal analysis, electronic and infrared spectra and magnetic and cyclic voltammetry measurements.

Analysis, $\left(\mathrm{H}_{2}\right.$ otscb): C. $34.52(34.50): \mathrm{H}, 5.81(5.74) ; \mathrm{N}$, 31.95 (32.16); [Cu(Hotscb) $\left.\left(\mathrm{NO}_{3}\right)\left(\mathrm{H}_{2} \mathrm{O}\right)\right]$ : C. 19.39 (18.92); H, $3.44(3.47) ; \mathrm{N}, 21.67(22.06) ;[\mathrm{Ni}(\text { otscb })]_{2}: \mathrm{C}, 26.44$ $(25.80) ; \mathrm{H}, 4.30(4.30) ; \mathrm{N}, 23.73$ (24.06); [Pd(otscb)] $; \mathrm{C}$. $21.89(21.44) ; \mathrm{H}, 2.76(2.87) ; \mathrm{N}, 19.14(19.94)$. The calculated values are shown in parentheses.

Physical and spectral measurements: ' $H-n, m, r$ spectra were recorded on a Varian spectrometer using DMSO as solvent. Chemical shifts $(\delta)$ are reported in p.p.m relative to $\mathrm{Me}_{4} \mathrm{Si}$, Infrared spectra were obtained on Nicolet $510 \mathrm{OP}-\mathrm{FT}$ IR spectrometer with samples prepared as $\mathrm{KBr}$ pellets. Solution (DMSO solution in I cm cells) electronic spectra were recorded with lambda 25 UV-vis spectrometer. Magnetic susceptibility measurement (Table 1) were carried out at room temperature $(298 \mathrm{~K})$ using Johnson Matthey susceptibility balance and calculations were made using computed values of Pascal constants for diamagnetic corrections. Molar conductivities $\left(10^{-3} \mathrm{M}\right.$ in DMSO) were measured with CMD 8500 [ aboratory Conductivity Meter (Table 1). Thermogravimetric data were obtained on Perkin-Elmer ]GA7 unit (heating rate $5^{\circ} \mathrm{C}, \mathrm{min}^{-1}$ ). Cyclic voltammetric

Table 1. Colours. maenctic susceptibilitjes and molar conductivities of ligand ( $\left.\mathrm{H}_{z} \mathrm{otsch}\right)$ and its complexws

\begin{tabular}{|c|c|c|c|}
\hline Compound & Colour & $\mu_{\text {erf }}$ B.M & $\begin{array}{c}10^{3} \mathrm{M} \mathrm{IDMSO} \\
\mathrm{\Lambda}_{\mathrm{M}} \mathrm{ohm}^{-1} \mathrm{~mol}^{-1}\end{array}$ \\
\hline$\left(\mathrm{I}_{2} \mathrm{otscb},(\mathrm{II})\right.$ & White & & \\
\hline $\begin{array}{l}\text { lCu(Holscb) }\left(\mathrm{NO}_{3}\right)\left(\mathrm{H}_{2} \mathrm{O}\right) \mathrm{I} \\
\text { (III) }\end{array}$ & Green & 1.885 & 25.0 \\
\hline $\mid$ Ni(otscb)| $\left.\right|_{2}(\mathbf{I V})$ & 13rowin & Diamagnetic & 7,0 \\
\hline$\left|P_{d} d(o l s c b)\right|_{2}(V)$ & Red & Diamagnetic & 40 \\
\hline
\end{tabular}

studies were carried out on a potentiostate/wave generator (Oxford Electrodes). Using a platinum working electrode, in conjunction with a Phileps PM $8043 \mathrm{x}-\mathrm{y}$ recorder.

\section{Results and Discussion}

The synthesis of 2-oximino-3-thiosemicarbazone-2,3butanedione $\left(\mathrm{H}_{2} \mathrm{otscb}\right)$ (II) was accomplished in good yield $(85 \%)$ by reacting 2,3 -butanedione monoxime with thiosemicarbazide in aqueous $\mathrm{\Gamma} . \mathrm{OH}$ at $100^{\circ} \mathrm{C}$ after recrystallization from $\mathrm{EtOH}$ (Scheme 1).

The structure proposed for this ligand is consistent with data obtained from elemental analysis data and 'H-n,m,r spectrum. In the proposed structure of the ( $\mathrm{H}_{2} \mathrm{otscb}$ ), three sites are available for the complexation of metal ions in mononuclear copper complex (III) as depicted in Figure 1. Additional site arrising from oxime oxygen atom is involved in complexation of metal ions in dinuclear nickel and palladium complexes (IV-V) shown in Figure 1.

The colours molar conductivities and magnetic susceptibilities of the metal complexes of $\left(\mathrm{H}_{2} \mathrm{otscb}\right)$ are shown in Table 1. Brown and Green colours are common to complexes<smiles></smiles>

(III)

$\left[\mathrm{Cu}\left([\mathrm{lolsb})\left(\mathrm{NO}_{3}\right)\left(\mathrm{I}_{2} \mathrm{O}\right)\right]\right.$

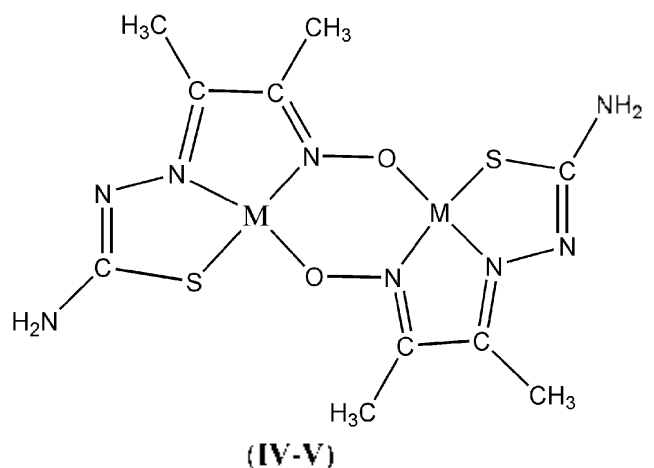

$[\mathrm{M}(\mathrm{otscb})]_{2}$

(IV): $\mathrm{MI}=\mathrm{Ni}(\mathrm{II})$

(V):M $=\mathrm{Pd}(\mathrm{II})$

Figure 1. Structures of $\mid\left(\mathrm{u}(\mathrm{llotscb})\left(\mathrm{NO}_{3}\right)\left(\mathrm{I}_{2} \mathrm{O}\right) \mid\right.$ and $|\mathrm{M}(\mathrm{otscb})|_{2}$. $(\mathrm{M}=$ Vi(II)). Pd(II)) complexes.<smiles>CC(=O)/C(C)=N\O</smiles> 
involving thiosemicarbazone coordination due to the sulphurto-metal charge transfer bands. which dominate their visible spectra. ${ }^{16}$ The low values of molar conductance $\left(10^{-3} \mathrm{M}\right.$ in DMSO) for the $\mathrm{Ni}(\mathrm{II})$ and $\mathrm{Pd}(\mathrm{II})$ complexes indicate a nonelectrolyte behavior which is consistent with the proposed dimeric structure. For the $\mathrm{Cu}$ (II) complex, however. the presence of a snall number of ions may be attributed to replacement of the nitrato ligand by the solvent molecules. ${ }^{17}$ The magnetic susceptibilities values obtained for $\mathrm{Ni}(\mathrm{II})$ and Pd(II) complexes are consistent with diamagnetic structures given to the complex (low spin $\mathrm{d}^{8}$ ). However the value $\mu_{\text {eff }}=$ $1.885 \mathrm{BM}$ for $\left[\mathrm{Cu}(\right.$ Hotscb $\left.)\left(\mathrm{NO}_{3}\right)\left(\mathrm{H}_{2} \mathrm{O}\right)\right]$ showed that it is paramagnetic and confinmed the +2 oxidation state of copper

The ${ }^{1} \mathrm{H}$-n.m.m. data for $\left[\mathrm{H}_{2} \mathrm{otscb}\right]$ and its $\mathrm{Ni}(\mathrm{II})$ and $\mathrm{Pd}(\mathrm{II})$ complexes in DMSO have been analysed. For the free ligand, the two $\mathrm{CH}_{3}$ protons gave two singlets at $\delta 2.00$ p.p.m, and $\delta 2.25$ p.p.m. The $\mathrm{OH}, \mathrm{NH}$ and $\mathrm{NH}_{2}$ protons appeared as singlets at $\delta 11.61, \delta 10.26$ and $\delta 7.9$ p.p.m respectively. For the complexes the resonance arising from the oxime hydroxyl proton and $\mathrm{NH}$ proton disappeared whereas that arising from $\mathrm{NH}_{2}$ protons are shifted upfield. The absence of any $\mathrm{OH}$ and $\mathrm{NH}$ protons signals indicate involvenent in complexation with nickel and palladium metal ions.

The infrared absorption bands are most useful for determining the ligand's mode of coordination. These absorptions are given and assigned in Table 2 . No characterestic absorption assignable to $\mathrm{C}=\mathrm{O}$ function was found. confirming the formation of the Schif base ligand. The shift of the imine $v(\mathrm{C}=\mathrm{N})$ band of the oxime thiosenicarbazones from 1595 $\mathrm{cm}^{-1}$ to $1527-1572 \mathrm{~cm}^{-1}$ for the metal complexes indicates coordination of the imine nitrogen. ${ }^{18.21}$ On loss of $-\mathrm{NH}$ proton in thiosemicarbazone moiety in the complexes. an additional $v(\mathrm{C}=\mathrm{N})$ absorption is found at higher energy than $v(\mathrm{C}=\mathrm{N})$ of the uncomplexed thiosemicarbazone. ${ }^{21}$ In this study all synthesized complexes have shown this band at $1627-1633 \mathrm{~cm}^{-1}$. The spectra of the uncoordinated thiosemicarbazones show the thioanide IV band. which possesses a considerable contribution from $v(C S)$. in the $838 \mathrm{~cm}^{-1}$ region. This band shifts to a lower frequency $\left(55.100 \mathrm{~cm}^{-1}\right)$ on coordination of the anionic form of the thiosemicarbazones in agreement with previous studies of the thiosemicarbazone complexes. ${ }^{-13}$ Streching vibrations of $\mathrm{NO}$ in the oxime moiety in $\left(\mathrm{H}_{2} \mathrm{otscb}\right)$ were seen as medium-strong bands at $1366 \mathrm{~cm}^{-1} .^{2-4}$ The $v(\mathrm{~N}-\mathrm{O})$ streching vibrations for the dinuclear metal complexes (IV.V) shift to lower frequency and for the mononuclear complex to higher frequency suggesting that the oxime groups are nitrogen coordinated. The absence of $\mathrm{O}-\mathrm{H}$ streching vibrations for dinuclear complexes indicates that the oxime groups are oxygen coordinated too. Two oxime groups. which are derived from two different $\left(\mathrm{H}_{2} \mathrm{Otscb}\right)$ anions. are coordinated to two nickel (II) or palladium (II) ions to form six membered ring bridge ${ }^{55}$ The $v(\mathrm{MS})$ bands have been assigned in the $350 \mathrm{~cm}^{-1}$ region confirming the coordination of the sulphur atoms. ${ }^{26}$ Bands in the 470-502 $\mathrm{cm}^{-1}$ region are assigned to $v(\mathrm{MN})$ vibrations, supporting the coordination of the ligands as tridentate NNS chelating agents. ${ }^{2 z}$ The isolated dinuclear complexes (IV-V) show extra bands at $420 \mathrm{~cm}^{-1}$ which may be due to $v(\mathrm{MO})$ in these complexes and suggesting the coordination of the oxygen atoms. ${ }^{37}$ Absorption due to the nitrato ligand in momonuclear copper (II) complex (III) were found at $\mathrm{I} 405$ and $1311 \mathrm{~cm}^{-1} .8$

The infrared data confinns the existance of an unusual structural feature which consists of pair of metal ions (nickel or palladium) bridged by two oxime groups in a planar six membered ring conformation, Figure 1. All the infrared data support coordination of copper (II) ions to NNS doner groups of $\left(\mathrm{H}_{2} \mathrm{Otscb}\right)$ and to the nitrato monoligand and are consistent with the proposed structure for the mononuclear complex (Fig. 1).

The electronic absorption data (DMSO solution) are given in Table 3. Strong absorption in the uv range and a week absorption in the visible range are observed. The former may be attributed to the charge-transfer transition and is thought to be $\mathrm{d}-\Pi$ oximate in character. ${ }^{29}$ The latter may be attributed to the d-d transitions. The band at $380 \mathrm{~nm}$ in the nitrato complex (III) is absent in the spectra of (IV-V) complexes and is attributable to (nitrato $\mathrm{O} \rightarrow \mathrm{Cu}(\mathrm{II})$ ) ligand to metal charge transfer transition. ${ }^{1 \text { th }}$ The $\mathrm{d}$ - $\mathrm{d}$ band of complex (III) is similar to those shown by five coodinate $\mathrm{Cu}$ (II) complexes. ${ }^{27.31 .31}$ In all complexes. $\mathrm{d}$-d transitions were observed at $c a 480-$ $603 \mathrm{~nm}$. The energy of the d-d transition of complex (III)

Table 2. Infrared spectra and assignnents of 2-oxinino-3-thiosemicarbazone-2,3-butanedione (Hotscb) and its metal ion complexes ( $\mathrm{cm}^{-1}$ )

\begin{tabular}{|c|c|c|c|c|c|c|c|c|c|}
\hline Compound & $v(\mathrm{OH})$ & $v(\mathrm{NH})$ & $\begin{array}{c}v(\mathrm{C}=\mathrm{N}) \\
\text { imine or oxime }\end{array}$ & $v(\mathrm{~N}-0)$ & $v(C S)$ & $v(\mathrm{MN})$ & $v(\mathrm{MO})$ & $v(\mathrm{MS})$ & Others \\
\hline$\left(\mathrm{H}_{2} \mathrm{Otscb}\right),(\mathbf{I I})$ & 3411 & $\begin{array}{l}3233 \\
3144\end{array}$ & 1594 & 1366 & 838 & & & & \\
\hline$\left[\mathrm{Cu}(\mathrm{Hotscb})\left(\mathrm{NO}_{3}\right)\left(\mathrm{H}_{2} \mathrm{O}\right)\right],(\mathbf{I I})$ & 3411 & $\begin{array}{l}3288 \\
3133\end{array}$ & 1572 & 1377 & 778 & 470 & - & 350 & $\begin{array}{r}1633 ; \mathrm{C}=\mathrm{N} \\
\text { New } \\
1405 ; \mathrm{NO}_{3}^{-} \\
1311 ; \mathrm{NO}_{3}^{-}\end{array}$ \\
\hline$[\mathrm{Ni}($ otscbi) $],(\mathbf{I V})$ & - & $\begin{array}{l}3288 \\
3133\end{array}$ & 1572 & 1333 & 783 & 502 & 420 & 350 & $\begin{array}{r}1627 ; \mathrm{C}=\mathrm{N} \\
\text { New }\end{array}$ \\
\hline$[\mathrm{Pd}(\text { otscb })]_{2},(\mathrm{~V})$ & - & 3277 & 1527 & 1322 & 738 & 489 & 422 & 350 & $\begin{array}{r}1627 ; \mathrm{C}=\mathrm{N} \\
\text { New }\end{array}$ \\
\hline
\end{tabular}


Table 3. Electronic spectra, cyclic voltanmetric and TG data for complexes

\begin{tabular}{|c|c|c|c|c|c|c|c|c|c|c|}
\hline \multirow[t]{2}{*}{ Compound } & \multicolumn{4}{|c|}{$\begin{array}{c}\text { U.V. visible data } \\
\lambda_{\max }, \operatorname{nun}\left(\varepsilon, \mathrm{M}^{-1} \mathrm{~cm}^{-1}\right)\end{array}$} & \multicolumn{2}{|c|}{$\begin{array}{l}\text { Cyclic Voltamunetric } \\
\text { data }\end{array}$} & \multicolumn{2}{|c|}{$\begin{array}{c}\text { TG data* } \\
\text { Decom. Temp. range } \mathrm{C}^{\circ}\end{array}$} & \multicolumn{2}{|c|}{ Other fragments } \\
\hline & $\mathrm{d}-\mathrm{d}$ & $\mathrm{O} \rightarrow \mathrm{M}(\mathrm{II})$ & S-M(II) & $\mathrm{n} \rightarrow \pi^{*}$ & $E p_{c} V$ & $E p_{0} V$ & $\mathrm{H}_{2} \mathrm{O}$ & $\mathrm{NO}_{3}$ & $\mathrm{CH}_{3} \mathrm{C}=\mathrm{NO}$ & $\mathrm{NH}_{2} \mathrm{CSN}$ \\
\hline $\begin{array}{l}{\left[\mathrm{Cu}(\mathrm{Hotscb})\left(\mathrm{NO}_{3}\right)\left(\mathrm{H}_{2} \mathrm{O}\right)\right]} \\
\text { (II) }\end{array}$ & $\begin{array}{l}603 \\
(373)\end{array}$ & $\begin{array}{c}380 \\
(555)\end{array}$ & - & $\begin{array}{c}306 \\
(16250)\end{array}$ & $\begin{array}{r}0.47 \\
-0.05\end{array}$ & $\begin{array}{l}0.75 \\
0.275\end{array}$ & $\begin{array}{l}118-130 \\
5.66(5.68)\end{array}$ & $\begin{array}{c}225-245 \\
20.3(19.55)\end{array}$ & $\begin{array}{l}270-295 \\
18(17.98)\end{array}$ & - \\
\hline$[\mathrm{Ni}(\mathrm{otscb})]_{2},(\mathbf{I V})$ & $\begin{array}{c}490 \\
(625)\end{array}$ & - & $\begin{array}{c}344 \\
(9000)\end{array}$ & $\begin{array}{c}303 \\
(15050)\end{array}$ & $\begin{array}{l}0.62 \\
-0.125 \\
-0.75 \\
-1.185\end{array}$ & $\begin{array}{c}0.87 \\
0.375 \\
-0.25 \\
-1.06\end{array}$ & $\overline{-}-$ & - & - & $\begin{array}{l}342-380 \\
33(31)\end{array}$ \\
\hline$[\mathrm{Pd}(\text { otscb })]_{2},(\mathrm{~V})$ & $\begin{array}{c}480 \\
(506)\end{array}$ & - & $\begin{array}{c}340 \\
(4891)\end{array}$ & $\begin{array}{c}302 \\
(11950)\end{array}$ & - & - & - & - & - & $\begin{array}{l}287-380 \\
\underline{28}(27.7)\end{array}$ \\
\hline
\end{tabular}

*Under line data represent a ${ }^{\circ}$ o of found weight loss and (Caled).

sugests distorted square pyrinidal geonetry. ${ }^{32}$ The bands near 340 un for complexes (IV-V) are due to $\mathrm{S}(\sigma . \pi) \rightarrow$ M(II) charge transfer bands. ${ }^{13}$

The therntal behavior of the reported complexes was investigated using T.G. technique and the resulting data are given in Table 3. The T.G. curve of $\left[\mathrm{Cu}(\mathrm{Hotscb})\left(\mathrm{NO}_{3}\right)\right.$ $\left.\left(\mathrm{H}_{2} \mathrm{O}\right)\right]$ (III) $\left(5^{\circ} \mathrm{C} \mathrm{min} \mathrm{min}^{-1} 0.780 \mathrm{mg}\right)$ shows a weight loss of $5.66 \%$ occurs over the temperature $118-130^{\circ} \mathrm{C}$. The weight loss agrees well with that calculated value for the loss of one molecule of water $\left(5.68 \%\right.$ ). Between $225-245^{\circ} \mathrm{C}$. a further loss in weight $20.3 \%$ was found which agrees reasonably with the theoretical value for complete loss of a nitrate group $(19.55 \%)$. A third weight loss of $18 \%$ was found between $270-295^{\circ} \mathrm{C}$ which may corresponds to release of $\mathrm{CH}_{j}-$ $\mathrm{C}=\mathrm{N}-\mathrm{O}$ fragment $(17.98 \%)$. Thermograms of $\mathrm{Ni}(\mathrm{II})$ and $\mathrm{Pd}(\mathrm{II})$ complexes (IV-V) are very sintilar and shows higher thermal stability than $\mathrm{Cu}$ (II) complex (III). The thermogram of $[\mathrm{Ni} \text { (otscb) }]_{2}\left(5^{\circ} \mathrm{C} \mathrm{min}{ }^{-1} .0 .424 \mathrm{mig}\right)$ shows the first weight loss endothern between $287.380{ }^{\circ} \mathrm{C}$ which may be attributed to the release of two $\mathrm{NH}_{2} \mathrm{CSN}$ fragments ${ }^{33}$ (found $28 \%$, calcd $27.7 \%$ ). The last step for the degradation of all complexes under investigation may be due to the formation of nixed metal oxide and sulphate. ${ }^{34}$

The electrochenical properties of the complexes in organic media were investigated by cyclic voltanmetry. The data are sunmerised in Table 3. The I-E profiles of the mono- and dinuclear complexes are different and their cyclic voltammogranıs are shown in Figure 2. The voltammogran of $\mathrm{Cu}(\mathrm{II})$ complex in DMSO [0.1 M $\left.\left(n-\mathrm{Bu}_{4} \mathrm{~N}\right) \mathrm{PF}_{6}\right]$ exhibited two irreversible couples. The couple $\mathrm{Cu}(\mathrm{III} / \mathrm{II})$ showed two waves at $E_{p a}=0.75 \mathrm{~V}$ and $E_{p c}=0.47 \mathrm{~V}$. The couple $\mathrm{Cu}(\mathrm{II} / \mathrm{I})$ waves appear at $E_{p a}=0.275 \mathrm{~V}$ and $E_{p c}=-0.05 \mathrm{~V}$. The $\Delta E_{p}$ for the two couples show that the two processes are irreversible. The binuclear Ni(II) complex showed two successive couples. The waves of the first couple appear at $E_{p a}=0.87 \mathrm{~V}$ and $E_{p c}$ $=0.62 \mathrm{~V}$. The second couple waves appear at $\mathrm{E}_{\mathrm{pa}}=0.375 \mathrm{~V}$ and $E_{p c}=-0.125 \mathrm{~V}$. These successive couples corresponding to the oxidation of the two Ni(II) ions forming Ni(III). The oxidation of the first $\mathrm{Ni}$ (II) ions make the oxidation of the second $\mathrm{Ni}$ (II) ion more difficult and appear at higher potential. Two other successive couples appeared in the voltammogram of $\mathrm{Ni}$ (II) complex. The wave of the first couple appear at $\mathrm{E}_{\mathrm{F}^{\mathrm{a}}}=-0.25$ and $\mathrm{E}_{\mathrm{Fc}^{\mathrm{c}}}=-0.75 \mathrm{~V}$. The secnd couple shows its waves at $E_{p a}=-1.06$ and $E_{p c}=-1.185 \mathrm{~V}$. These couples are due to the $\mathrm{Ni}$ (IV/I) of the two Ni(II) ions in the binuclear complex. The voltammogram of binuclear Pd(II) complex (not shown) exhibited similar behaviour to that shown by $\mathrm{Ni}(\mathrm{II})$ complex, but the peaks are not very well defined.

\section{References}

1. Magnetostuctwal Comtations in Exchange Coupled System: Willett. R. D.: Gatteschi. D.: Kahn. O.. Eds.: Reidel: Dordrecht. Holland. 1985.

2. Molecular Magnetic Material, NATO. ASI Series: Gatteschi, D. Kahn. O.: Miller. J. S.; Palacio. F., Eds : Kluwer: Dordrecht. 1991.

3. Zhuang. Z. J.: Okawa. H.: Matsumoto, N.: Sakiyama. H.: Kida, S J. Chem. Soc. Dalton Trans. 1991.497.

4. Lehn1. J. M. Angew: Chem., Int Ed. Engl. 1988. 27.89.

5. Vigato. P. A.: Fenton. D. E. Coord. Chem. Rst 1990. 106. 25.

6. Liao. Z:: Liu, W.: Liu, J; Jiang. Y; Shi. J.: Lin, C. J. hong. Chent 1994. 55,165

7. Güner. S.: Karaböcek, S. J. Biochent. Mol. Toxicol 1998. 12. 53.

8. Karaböcek. S.: Güner. S.: Karaböcek. N. Transition Met Chem. 1998. 23. 159 .

9. Costa. G.: Mestroni. G.: de Savorgnaric. E. Inorg. Chem. Acta 1969. 3, 323 .

10. Serbest, K.: Dedirmencioðlu, I:- Karaböcek, S.; Güner, S. Transition Met. Chent 2001. 26,232.

11. Basuli. F.: Peng. S. M.: Bhattacharya. S. horg. Chim 1997. 36. 5645 .

12. (a) Camphell. M. J. M. Coord. Chem. Rev 1975. 15. 279. (b) West, D. X: Liberta. A. E.: Padhye. S. B.: Chikate, R. C.: Sonawane, P. B.: Kumbhar. A. S.; Yerande. R. G. Coond Chent. Rev 1993.123,49.

13. Chattopadhyay. D.: Mazandar. S. K.: Banerjee. T.: Ghost. S.: Mak. T. Acta Coystallog: 1988. CH4. 1025.

14. (a) De Bolfo. A.: Smith. T. D.: Boas. J. F.: Pilbrow. T. R. Aust. J. Chent 1976, 29. 2583. (b) West, D. X; Yang. Y. H.: Klein. T. L.: Goldberg, K. I.: Liberta. A. E.; Valdes Martinez. J.: Joscano. R. A. Pothetrot 1995, 14. 1681 .

15. (a) Brown. D. G. Prog. Inorg Chem 1973. 18. 17. (b) Thomas. T. W.: Underhill. A. E. Chem. Soc. Rev 1972. 1.99. (c) Underhill. A. E.: Watkins. D. W.: Petrig. R. Inorg. Nucl. Chem. Lett 1973. 9. 1269.

16. Swearingen, J. K.: West. D. X. Tramsition Het Chent. 2001, 26. 252 .

17. Geary. W. I. Coord. Chem Rev 1971. 7.81.

18. Sousa. P.: Garcia-Vazquez. I. A.: Masaquer. T. A. Transition Met. 
Chem. 1984. 9. 318 .

19. Agrawal. S. K.: Tultani. D. R.: Gupta. R.: Hajela. S. K. Inorg. Chim. Acta 1987, 129,257.

20. Saha, N.: Sinha, S. Indian J. Chem 1990, 29.4. 292.

21. West. D. X.: Swearingen. J. K.: Valdes-Martinez. J: HernandezOrtega. S.: El-Sawaf. A. K.: Van Meurs. F.: Castineiras. A.: Garcia. I.: Bermejo. E. Polyhedron 1999. 18. 2919.

22. West. D. X: Beraldo. H.: Nassar. A. A.: El-Saied. F. A.: Avad. M. I. Transition let Chem 1999, 24. 421 .

23. West. D. X.: Salberg, M. M.: Bain, G. A.: Liberta, A. E. Transition Het. Chent 1997. 22. 180.

24. Blinc. R.: Hadzi. D. J. Chem. Soc. A 1958. 4536.

25. Song. Y: Chen. X. T: Zheng. C. G.: Zhu. D. R.: You. X. Z. Transition Metal them. 2001. 26.247.

26. De Voto. G.: Massacesi. M.: Pinna. R.; Ponticelli. G. Spectrochint. Acta 1982. 38.4, 725
27. Bindu. P.: Kurup. M. R. P.: Satyacheeıty. T. R. Polyhedron 1999. 18. 321 .

28. Nakamoto. K. Infrared and Raman Spectra of honganic and Coordination Conpoumds. $5^{\text {th }}$ Ed.: Wiley: New York 1997; Part B. $p 87$.

29. Blinc. R.: Hadzi. D. J. Chem. Soc. A 1958. 4536.

30. Garia. T. T.: Lezama. L.: Pizarro. I. L.: Instausti. M.: Arriotuo. M. I.: Rojo. T. Polyhedren 1999. 18. 3703.

31. Goodgame. D. M. L.: Rayner Cenham. G. W. J. Chem. Soc. A 1971. 1923.

32. Ruiz. R; Sanz. J : Cervera, B.; Lloret. F.; Julve, M.: Bois, C.; Faus. T.: Murnoz. M. C. J. Chem. Soc. Dalton Trons. 1993. 1623.

33. Zayed. M. A.: Nour El-Dein. F. A. Thermochim Acta 1987. 114. 53.

34. Steger, H. F. J. Whot Nucl Chem. 1972, 34. 175. 